\title{
Development and Validation of an GC-MS Method to Quantify Phytoconstituents by Using Entada pursaetha DC
}

\author{
Valarmathi $\mathbf{S}^{1, *}$ K. Raju${ }^{1}$, Arul Kumar Murugesan ${ }^{2}$ \\ ${ }^{1}$ P.G. and Research Department of Botany, Kandaswami Kandar's College, India \\ ${ }^{2}$ Department of Botany, Bharathidasan University, Tiruchirappalli, India
}

Received November 11, 2019; Revised December 18, 2019; Accepted December 25, 2019

Copyright $\odot 2020$ by authors, all rights reserved. Authors agree that this article remains permanently open access under the terms of the Creative Commons Attribution License 4.0 International License

\begin{abstract}
Medicinal plants have rich source of secondary metabolites, which can be screened either qualitatively or quantitatively. It is an important procedure for qualifying the plant drug and their potentialities. The active phytomoleucles present in a plant reflect the therapeutic values of medicinal species. In order to discover a new bioactive compounds from plant resources which could become new leads or new drugs, plant extracts should be simultaneously evaluated by appropriate screening methods by either biological or pharmacological targets. For the extraction procedures, solvent extraction is commonly employed for extraction of most active principles from the plants. Entada sp. showed more than 27 different components of phytochemicals with a rich source of polysaccharides whereas polysaccharides only have major drug potential which was carried out by GC-MS analysis. In the recent studies, the bioactive components of seed of Entada pursaetha using GC-MS were investigated using Perkin-Elmer Gas Chromatography-Mass Spectrometry, while the Mass spectra of the compounds found in the extract was matched with previous literature.
\end{abstract}

Keywords Stem, Leaf, Compounds, Retention Time, Chemical Formula, GC-MS

\section{Introduction}

Medicinal plants are being the main resource of secondary metabolites which can be used as potent drugs. They have been an important source of medicine for curing innumerable ailments since thousands of years. Mainly old traditional remedies as world history of wisdom, they had been used as popular folk medicines (Sathyaprabha et al., 2010). Based on the in-vitro screening of phytochemical method has supported to conceive the preliminary knowledge to elect crude plant extracts with useful properties for future studies and analysis research towards secondary phytochemical and pharmacological investigations (Mathekaga and Meyer, 1998).

Kalimuthu and Prabakaran (2013) reported that the medicinal plants are increasingly valuable importance for extracting principal resources of nutraceuticals, traditional medicines and food supplements. The official values of medicinal plants are depending on their bioactive phytoconstituents. These phytoconstituents are being identified in medicinal plants can be used to cure many diseases and disorders and can be studied for their definite physiological activity in the human body. The isolation, identification and screening of chemical constituents present in herbal medicines have been of great interest to the scientists for discovering novel therapeutic drugs, and the effective in remedy for several diseases (Sylvestrea $e t$ al., 2006).

Currently, Gas Chromatography-Mass Spectrometry (GC-MS) has become firmly established as a key technological platform for secondary metabolite profiling in both plant and non-plant species (Robertson, 2005). More recently, detailed studies on phytochemical constituents and their pharmacological properties of $E$. africana have been elucidated by Yusuf and Abdullahi (2019). Entada phaseoloides is an important medicinal species in China and Taiwan, which has been detected the two new derivatives of Dihydroxyphenylacetic acid (Chen et al., 2013) and phenolic acid glucosides (Singh et al., 2011). Entada abyssinica is also having rich sources of phehnolic saponins and antioxidant glycosides which have been carried out antimicrobial and antioxidant properties (Teke et al., 2011). The study revealed major bioactive compounds present in the plant part extract. Identification of these compounds in the plant serves as the basis in 
determining the possible health benefits of the plant leading to further biologic and pharmacologic studies (Denwick, 2002).

\section{Materials and Methods}

\subsection{Collection of Plant Material}

The entire herb of Entada pursaetha DC plant was collected from the nearby area of Kollihills, Namakkal District fields (Tamil Nadu). The shade tried plant parts of E. pursaetha were pulverized to powder in a mechanical grinder. The required quantity of powder was weighed and extracted with a standard procedure.

\subsection{Preparation of Extracts}

A portion of dried aerial parts (100 g) of Entada pursaetha DC was placed in a soxhlet apparatus. Extraction was performed with $700 \mathrm{ml}$ of methanol for 48 hours at a temperature not exceeding the boiling point of the solvent. The collected extract was filtered through a $45 \mu \mathrm{m}$ filter (Hsouna et al., 2011). The filtered solute was concentrated in vacuum to dryness to give methanol extract. And then, the extract was stored in a refrigerator at $4^{\circ} \mathrm{C}$ for further use and the sample extract was then subjected to GC-MS analysis.

\subsection{GC-MS Analysis}

Gas-Liquid Chromatography coupled to Mass Spectrometry (GC-MS) was performed to identify the chemical constituents of essential oils (Yang et al., 2007). For that, the Clarus 680 GC was used in the analysis, a fused silica column packed with Elite-5MS (5\% biphenyl $95 \%$ dimethylpolysiloxane) (30 m x $25 \mu \mathrm{m}$ film thickness) and the individual component was separated by using Helium as carrier gas at a constant flow of $1 \mathrm{ml} / \mathrm{min}$. The $1 \mu \mathrm{L}$ of essential oil injected into the instrument the oven temperature was as follows: Initial temperature $60^{\circ} \mathrm{C}$ for 2 min, ramp $10^{\circ} \mathrm{C} / \mathrm{min}^{-1}$ to $300^{\circ} \mathrm{C}$, hold $6 \mathrm{~min}$, Injection auto temperature $260^{\circ} \mathrm{C}$; and Split injection flow ratio, 10:1. The mass detector Conditions were: transfer line temperature $240^{\circ} \mathrm{C}$ and ion source temperature were $240^{\circ} \mathrm{C}$; and ionization mode electron impact at $70 \mathrm{eV}$, with a scan time $0.2 \mathrm{sec}$ and scan interval of $0.1 \mathrm{sec}$ the fragments from 40 to $600 \mathrm{Da}$. In this, one micro litre of the samples was loaded for the analysis. The sample was detected at different retention time by The South Indian Textile Research Association (Coimbatore, India). The retention factors in the spectrum were then compared with the library.

\subsection{Identification of Phytocomponents}

Interpretation on mass-spectrum GC-MS was conducted using the database of National Institute Standard and Technology (NIST) having more than 62,000 patterns. The spectrum of the unknown components was compared with the spectrum of known components stored in the NIST library. The name of phytocompounds, molecular weight, and percentage of distribution of the test materials were tabulated.

\section{Results}

Gas Chromatography-Mass Spectrometry (GC-MS) is a combined technique which is used for identifying different compounds or biochemical substances sample extracts. It works on the separation of the individual compound by gas chromatography (GC). According to their retention time (RT), the separated compounds were further analyzed at a molecular level by mass spectrometry (MS). The GC-MS analysis revealed the presence of phytochemical constituents from which some are higher hydrocarbon alkanes, ester, terpenes, flavonoids, organic compounds, steroids, and fatty acids.

The GC-MS Chromatogram (Fig. 1) showed 7 distinct peaks on the basis of RT and each peak depicted a phytocompound with specific molecular weight in leaf extract of E. purseatha. It can be identified along with their chemical structure MS spectrum. The name of phytochemical compounds, molecular formula, molecular weight, probability percentage at retention time (RT), and corresponding peak area \% were listed in Table 1. The compounds are identified by the GC-MS analysis and their chemical formula viz, Triethoxysilanol $\left(\mathrm{C}_{6} \mathrm{H}_{16} \mathrm{O}_{4} \mathrm{Si}\right)$, Benzoic acid,2-hydroxy-,methyl ester $\left(\mathrm{C}_{8} \mathrm{H}_{8} \mathrm{O}_{3}\right)$, 2-nitro1,3-propanediol $\quad\left(\mathrm{C}_{10} \mathrm{H}_{16}\right), \quad$ 1,1-Difluoro-2-(2,4difluorophenyl)-1-(2-quinolinyl)-3-(1,2,4-triazol-1-yl)-2propanol $\left(\mathrm{C}_{2} \mathrm{OH}_{14} \mathrm{~F}_{4} \mathrm{~N}_{4} \mathrm{O}\right)$ Hexadecanoic acid (CAS) $\left(\mathrm{C}_{16} \mathrm{H}_{32} \mathrm{O}_{2}\right)$, Octadecanoic acid $\left(\mathrm{C}_{18} \mathrm{H}_{36} \mathrm{O}_{2}\right)$, 2,5-bis $\left(4^{\prime}-\right.$ Methoxynaphthyl)thiophene $\left(\mathrm{C}_{26} \mathrm{H}_{20} \mathrm{O}_{2} \mathrm{~S}\right)$ respectively. The major compounds observed namely Benzoic acid and 1,1-Difluoro-2-(2,4-d ifluorophenyl)-1-(2-quinolinyl)-3(1,2,4-triazol-1-yl)-2-propanol. Other 5 compounds are trace in amount of distribution such as 2-hydroxy-, methyl ester (CAS), 2-nitro-1,3-propanediol, Hexadecanoic acid (CAS), Octadecanoic acid, and 2,5-bis(4'Methoxynaphthyl) thiophene. 


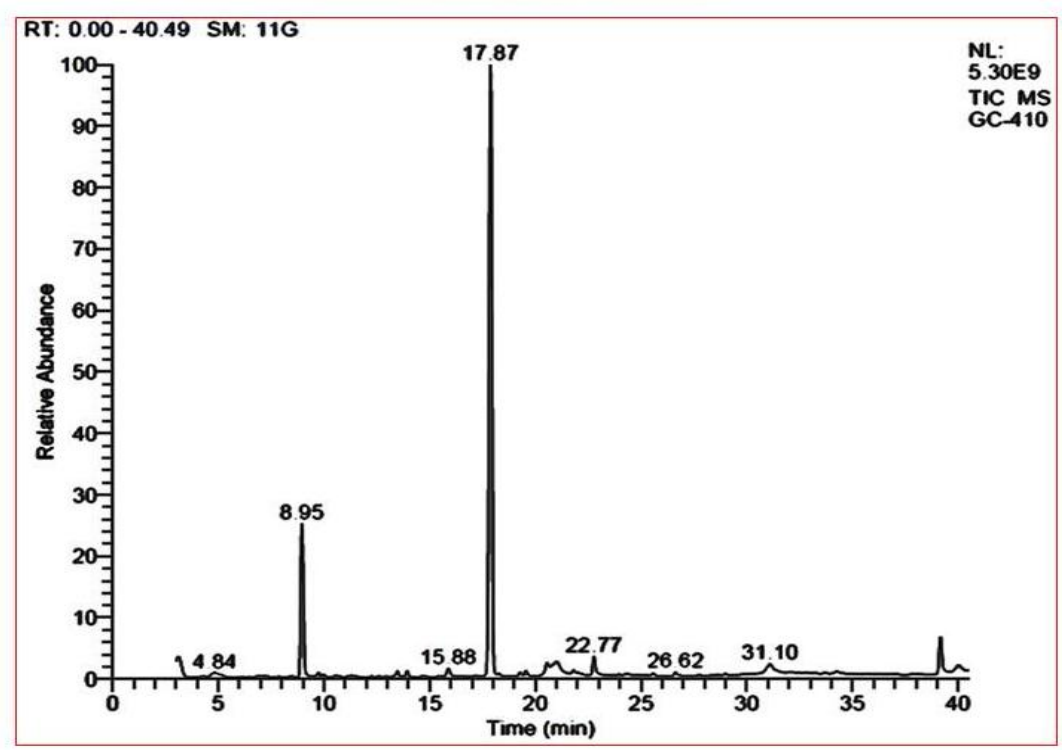

Figure 1. GC-MS Analysis of Ethanolic Leaf Extract of Entada pursaetha

Table 1. Phyto-Chemical Constituents from ethanolic extract of leaf and stem of E. pursaetha

\begin{tabular}{|c|c|c|c|c|c|c|}
\hline S.No & RT & & Name of Phy to-Chemical Constituents & $\begin{array}{l}\text { Molecular } \\
\text { Formula }\end{array}$ & $\begin{array}{l}\text { Molecular } \\
\text { Weight }\end{array}$ & Area\% \\
\hline 1 & 4.84 & \multirow{7}{*}{$\begin{array}{l}\text { Leaf } \\
\text { Extracts }\end{array}$} & Triethoxysilanol & $\mathrm{C}_{6} \mathrm{H}_{16} \mathrm{O}_{4} \mathrm{Si}$ & 180 & 1.23 \\
\hline 2 & 8.95 & & Benzoic acid,2-hydroxy-,methyl ester & $\mathrm{C}_{8} \mathrm{H}_{8} \mathrm{O}_{3}$ & 152 & 14.4 \\
\hline 3 & 15.88 & & 2-nitro-1,3-propanediol & $\mathrm{C}_{10} \mathrm{H}_{16}$ & 121 & 0.23 \\
\hline 4 & 17.87 & & $\begin{array}{l}\text { 1,1-Difluoro-2-(2,4-difluorophenyl)-1-(2-quinolinyl)-3-(1,2,4- } \\
\text { triazol-1-yl)-2-propanol }\end{array}$ & $\mathrm{C}_{20} \mathrm{H}_{14} \mathrm{~F}_{4} \mathrm{~N}_{4} \mathrm{O}$ & 402 & 62.8 \\
\hline 5 & 22.77 & & Hexadecanoic acid (CAS) & $\mathrm{C}_{16} \mathrm{H}_{32} \mathrm{O}_{2}$ & 256 & 1.75 \\
\hline 6 & 26.62 & & Octadecanoic acid & $\mathrm{C}_{18} \mathrm{H}_{36} \mathrm{O}_{2}$ & 284 & 0.57 \\
\hline 7 & 31.10 & & 2,5-bis(4'-Methoxynaphthyl)thiophene & $\mathrm{C}_{26} \mathrm{H}_{20} \mathrm{O}_{2} \mathrm{~S}$ & 396 & 1.78 \\
\hline 8 & 4.84 & \multirow{7}{*}{$\begin{array}{l}\text { Stem } \\
\text { Extracts }\end{array}$} & (+-)-trans-Ethoxy-2-(prop-1-ynyl) cyclohexane. & $\mathrm{C}_{11} \mathrm{H}_{18} \mathrm{O}$ & 166 & 0.90 \\
\hline 9 & 8.96 & & Benzoic acid, 2-hydroxy-methyl ester. & $\mathrm{C}_{8} \mathrm{H}_{8} \mathrm{O}_{3}$ & 152 & 16.40 \\
\hline 10 & 15.95 & & 6-Hepten-3-one, 4-methyl. & $\mathrm{C}_{8} \mathrm{H}_{14} \mathrm{O}$ & 126 & 0.68 \\
\hline 11 & 17.91 & & 24-Oxoalisol A. & $\mathrm{C}_{29} \mathrm{H}_{48} \mathrm{O}_{5}$ & 476 & 63.25 \\
\hline 12 & 21.78 & & Thiophene, tetrahydro-2-methyl. & $\mathrm{C}_{5} \mathrm{H}_{10} \mathrm{~S}$ & 102 & 4.54 \\
\hline 13 & 25.57 & & Eicosanebioic acid, dimethyl ester. & $\mathrm{C}_{22} \mathrm{H}_{42} \mathrm{O}_{4}$ & 370 & 0.38 \\
\hline 14 & 32.80 & & Hexadecanoic acid, 2-hydroxy-1 (hydroxymethyl) ethylester. & $\mathrm{C}_{19} \mathrm{H}_{38} \mathrm{O}_{4}$ & 330 & 0.23 \\
\hline
\end{tabular}

Among all the extracts were identified only limited number of phytochemicals from GC-MS profiling. Whereas only one phytocompound such as Benzoic acid methyl ester exhibited the common occurrence in all selected plant part extracts and is also a major constituent of all samples. Other major compounds are diverse nature of nitrogenous compound, some moneterpenes and diterpenes in trace to considerable percentage. The overall GC-MS analysis did not show that much varied the metabolite composition in E. pursaetha which stored unique metabolite which are responsible for their medicinal and pharmacological properties. The major compounds from E. pursaetha observed namely (+-)-trans-Ethoxy-2(prop-1-ynyl) cyclohexane $\left(\mathrm{C}_{11} \mathrm{H}_{18} \mathrm{O}\right)$, Benzoic acid, 2hydroxy-methyl ester $\left(\mathrm{C}_{8} \mathrm{H}_{8} \mathrm{O}_{3}\right)$, 6-Hepten-3-one, 4-methyl $\left(\mathrm{C}_{8} \mathrm{H}_{14} \mathrm{O}\right)$, 24-Oxoalisol A $\left(\mathrm{C}_{29} \mathrm{H}_{48} \mathrm{O}_{5}\right)$, Thiophene, tetrahydro-2-methyl $\left(\mathrm{C}_{5} \mathrm{H}_{10} \mathrm{~S}\right)$, Eicosanebioic acid, dimethyl ester $\left(\mathrm{C}_{22} \mathrm{H}_{42} \mathrm{O}_{4}\right)$ and Hexadecanoic acid, 2hydroxy-1(hydroxymethyl) ethylester $\left(\mathrm{C}_{19} \mathrm{H}_{38} \mathrm{O}_{4}\right)(\mathrm{Fig} .2$ \& Table 2). 


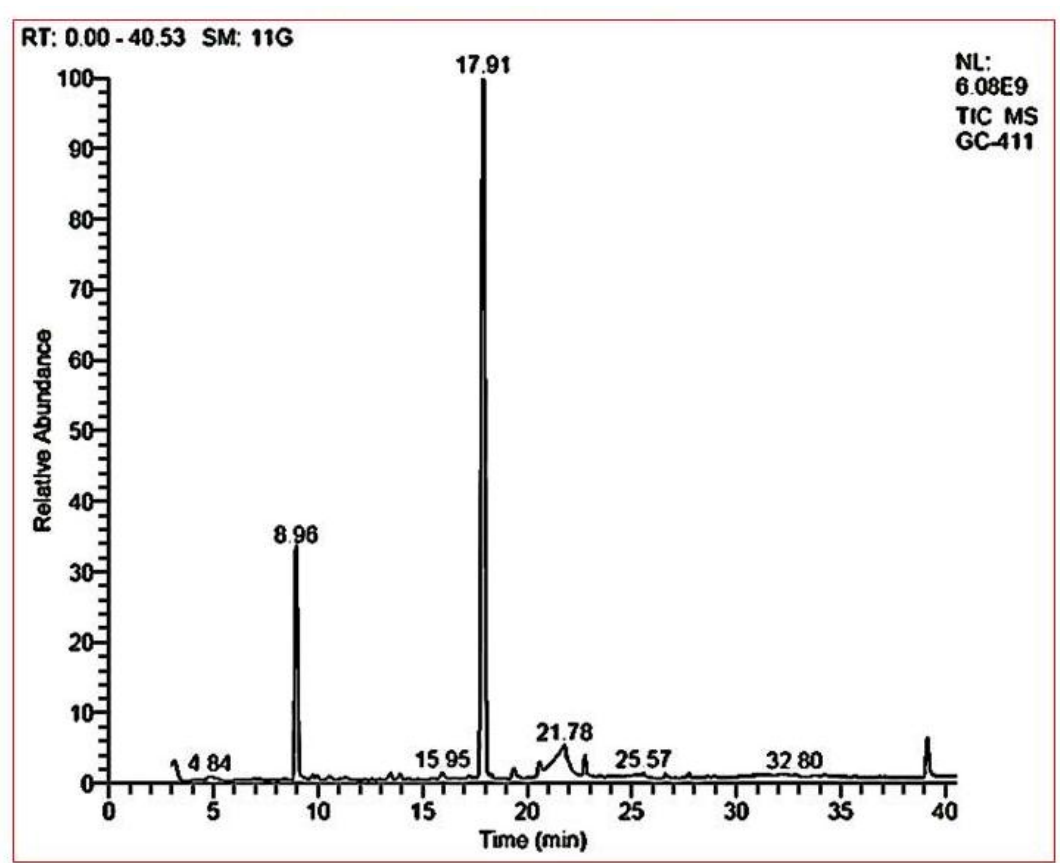

Figure 2. GC-MS Analysis of Ethanolic Stem Extract of Entada pursaetha

Table 2. Comparison of the Phyto-Chemical Constituents from ethanolic extract of leaf and stem of E. pursaetha

\begin{tabular}{|c|c|c|c|c|}
\hline S.No & \multicolumn{2}{|c|}{ Name of Phy to-Chemical Constituents } & $\begin{array}{l}\text { Molecular } \\
\text { Formula }\end{array}$ & References \\
\hline 1 & \multirow{7}{*}{ Leaf Extracts } & Triethoxysilanol & $\mathrm{C}_{6} \mathrm{H}_{16} \mathrm{O}_{4} \mathrm{Si}$ & Shalini et al., 2016 \\
\hline 2 & & Benzoic acid,2-hydroxy-,methyl ester & $\mathrm{C}_{8} \mathrm{H}_{8} \mathrm{O}_{3}$ & Kalpana et al., 2012 \\
\hline 3 & & 2-nitro-1,3-propanediol & $\mathrm{C}_{10} \mathrm{H}_{16}$ & Björn and Alexander, 2011 \\
\hline 4 & & $\begin{array}{l}\text { 1,1-Difluoro-2-(2,4-difluorophenyl)-1-(2- } \\
\text { quinolinyl)-3-(1,2,4-triazol-1-yl)-2-propanol }\end{array}$ & $\mathrm{C}_{20} \mathrm{H}_{14} \mathrm{~F}_{4} \mathrm{~N}_{4} \mathrm{O}$ & - \\
\hline 5 & & Hexadecanoic acid (CAS) & $\mathrm{C}_{16} \mathrm{H}_{32} \mathrm{O}_{2}$ & Radha et al., 2016 \\
\hline 6 & & Octadecanoic acid & $\mathrm{C}_{18} \mathrm{H}_{36} \mathrm{O}_{2}$ & Altameme et al., 2015 \\
\hline 7 & & 2,5-bis(4'-Methoxynaphthyl)thiophene & $\mathrm{C}_{26} \mathrm{H}_{20} \mathrm{O}_{2} \mathrm{~S}$ & - \\
\hline 8 & \multirow{7}{*}{ Stem Extracts } & (+-)-trans-Ethoxy-2-(prop-1-ynyl) cyclohexane. & $\mathrm{C}_{11} \mathrm{H}_{18} \mathrm{O}$ & $\begin{array}{l}\text { Karthikeyan \& Dhanapal, } \\
2016\end{array}$ \\
\hline 9 & & Benzoic acid, 2-hydroxy-methyl ester & $\mathrm{C}_{8} \mathrm{H}_{8} \mathrm{O}_{3}$ & Zhang \& Zhou, 2011 \\
\hline 10 & & 6-Hepten-3-one, 4-methyl & $\mathrm{C}_{8} \mathrm{H}_{14} \mathrm{O}$ & Schmeda Hirschmann, 2014 \\
\hline 11 & & 24-Oxoalisol A & $\mathrm{C}_{29} \mathrm{H}_{48} \mathrm{O}_{5}$ & Wagner et al., 2002 \\
\hline 12 & & Thiophene, tetrahy dro-2-methyl & $\mathrm{C}_{5} \mathrm{H}_{10} \mathrm{~S}$ & Thamburaj et al.,2013 \\
\hline 13 & & Eicosanebioic acid, dimethyl ester & $\mathrm{C}_{22} \mathrm{H}_{42} \mathrm{O}_{4}$ & Ponnaiah \& Yokeswari, 2018 \\
\hline 14 & & $\begin{array}{l}\text { Hexadecanoic acid, 2-hydroxy-1(hydroxymethyl) } \\
\text { ethylester }\end{array}$ & $\mathrm{C}_{19} \mathrm{H}_{38} \mathrm{O}_{4}$ & Esen \& Bilal, 2018 \\
\hline
\end{tabular}

\section{Discussion}

Entada pursaetha is rich sources of phytochemical and it has been elucidated from the GC-MS analysis of the plant part extracts that enlisted about 20 different phytomolecules with varied proportions (Tables $1-2$ ). The major compounds are observed two in each plant part extracts and similar observation was made from the same plant seed extract (Kalpana et al., 2012; Bhogireddy et al., 2015). Benzoic acid is major phytocompund reported in the current study. Whereas in allied species of E. africana is also noted the same compound but due to geographical isolation and topotype of the species may varied the percentage of proportions of active constituents (Dong $e t$ al., 2012; Singh et al., 2011). Various parts of the $E$. africana was reported different chemicals such as polysaccharides (Diallo et al., 2001), betulin (Kwaji et al., 2018), saponins (Yusuf et al., 2019) and glycosides (Kwajiet al., 2017). However, in E. pursaetha needs further study for extraction, isolation and characterization of 
tagged phytomolecules with specific geographical chemotype. E. rheedii is conspecific to E. pursaetha even though many researchers worked on that plant species and reported several chemical components which are active in antimicrobial, antioxidants, antiproliferative and other pharmacological properties (Nzowa et al., 2009; Chen et al., 2013).

Entadamide-A is a phenolic terpenoids is olated from the seeds of E.rheedii (Sufian et al., 2015) which has been investigated for biological activities. The seed extract of present results showed the corres ponding chemical moiety such as terpenoid derivatives obtained from GC-MS (Table 1). Many other studies are also noted the phytochemical profile of the Entada species and the phytocompounds are corresponding the pharmacological activities like antimicrobial and antioxidants (Rahman et al., 2013; Nathan, 2017). Nzowa et al., (2013) have been reported the tryptophan derivatives in seed kernel of $E$. rheedii. The present results are also on par with above investigation that has been enumerated many pyridine and purine compounds in E. pursaetha plant part extract (Tables 1-2).

The GC-MS results obtained from the study outlay on interesting with narrow array of phytocompounds. Entada pursaetha possess a good store of biochemical constituents which provides the basis of medicinal potential. The combined effects of those secondary compounds are responsible for the medicinal and therapeutic values. The prime phytochemical potential indulged in the E. pursaetha has been successfully explored as an outcome of this study.

\section{Conclusions}

The present findings were carried out to determine the possible bioactive components phytochemical of leaves and stem of $E$. pursaetha using GC-MS. However, isolation of individual phytochemical constituents of of leaves and stem of E. pursaetha using GC-MS and subjecting it to the biological activity will be definitely giving fruitful results and will open a new area of investigation of individual components and their pharmacological potency. From these results, it could be concluded that E. pursaetha contains various bio-active compounds. Evaluation of pharmacological activity is under progress. They phytochemicals detected were the higher hydrocarbon alkanes, ester, terpenes, flavonoids, organic compounds, steroids, and fatty acids. A few numbers of fatty acids were polyunsaturated and saturated fatty acids such as Tetradecanoic acid, n-Hexadecanoic acid. Therefore, it is recommended as a plant of phytopharmaceutical importance.

\section{REFERENCES}

[1] Abdullahi, M.I. (2019) The phytochemical and pharmacological actions of Entadaafricana Guill. \&Perr. Heliy on 5(9): e02323.

[2] Altameme, Huda, Hussein, Ameera, Hameed, Imad, Kareem, Muhanned. (2015) Determination of alkaloid compounds of Ricinus communis by using gas chromatography- mass spectroscopy (GC-MS). Journal of Medicinal Plant Research, 9, 349-359.

[3] Bhogireddy, N., Mathi, P., Ambatipudi, N., Talluri, V. and Bokka, V. R. (2015) In vitro anti-inflammatory and biofractionation of E. pursaetha DC ethanol seed extract in LPS induced RAW 264.7 macrophage cells. Adv. Biol. Res. 9:109-116.

[4] Björn Andreeßen and Alexander Steinbüchel. (2011) Serinol: small molecule - big impact. AMB Express, 1:12.

[5] Chen, L., Zhang, Y., Ding, G., Ba, M., Guo,Y. and Zou, Z. (2013) Two new derivatives of 2.5-Dihydroxy phenylactic acid from the kernel of Entadaphaseoloides. Molecules 18: $1477-1482$

[6] Chen, L., Zhang, Y., Ding, G., Ba, M., Guo,Y. and Zou, Z. (2013) Two new derivatives of 2.5-Dihydroxy phenylactic acid from the kernel of Entadaphaseoloides. Molecules 18: 1477-1482.

[7] Denwick, P. M. (2002) Natural Products: A Biosynthetic Approach. 2nd ed. England: John Wiley and Sons Ltd.

[8] Diallo, D., Paulsen, B.S., Liljeback, T.H.A. and Michaelsen, T.E. (2001) Polysaccharides from the roots of Entadaafricana Guill. etPerr., Mimosaceae, with complement fixing activity. J. Ethnopharmacology 74: 159171.

[9] Dong, Y., Shi, H., Yang, H. And Peng, Y. (2012) Antioxidant phenolic compounds from the stem of Entadapahseoloides. Chemistry \&Biodiverstiy 9(1): 68-79.

[10] Esen Sezen Karaoglan, and Bilal Yilmaz. 2018 Identification of bioactive compounds of Alchemilla caucasica using gas chromatography-mass spectrometry, International Journal of Pharmacognosy, 5(5): 287-293.

[11] Hsouna, A.B., Trigui, M., Mansour, R. B., Jarraya, R. M., Damak, M. and Jaoua, S. (2011) Chemical composition, cytotoxicity effect and antimicrobial activity of Ceratoniasiliqua essential oil with preservative effects against Listeria inoculated in minced beef meat. Int. J. Food Microbiol., 148:66-72.

[12] Kalimuthu, K. and Prabakaran, R. (2013) Preliminary phy tochemical screening and GC-MS analy sis of methanol extract of Ceropegiapusilla. Int. J. Res. Appl. Nat. Soc. Sci. 1(3):49-58.

[13] Kalpana, D.V., Shanmugasundaram, R. and Mohan, V.R. (2012) GC-MS analysis of ethanol extract of Entadapursaetha DC. seed. Biosicence Discovery. 3(1): 3033.

[14] Karthikey an K. and C. K. Dhanapal. (2016) GC-MS analy sis of methanol extract of Alysicarpus monilifer-whole plant. Der Pharma Chemica, 8(19):563-571.

[15] Kwaji, A., Adamu, H.M. and Chindo, I.Y. (2017) Phytochemical analysis, antibacterial and antioxidant activities of Entadaafricana Guill. And Perrott stem bark extracts. Res. J. Chem. Sci. 7(10): 10-155. 
[16] Kwaji, A., Adamu, H.M., Chindo, I.Y. and Atiko, R. (2018) Isolation, characterization and biological properties of betulin fromEntada africana Guill. andPerr. (Mimosaceae). J. Appl. And Adv. Res. 3(1): 28-31.

[17] Mathekaga, A. D. and Meyer. J. J. M. (1998) Antibacterial activity of South African Helichry sum species. South Afr. J. Bot. 64:293-5.

[18] Nathan, V.K. (2017) Phytochemical evaluation and antimicrobial efficacy ofEntada rheedii Spreng. Global J. Res. Analy sis 6(2): 624-625.

[19] Nzowa, L.K., Barbonii, L., Teponno, R.B., Ricciutelli, M., Lupidi, G., Quassinti, L., Bramucci, M. and Tapondjou, L.A. (2009) Rheediinosides A and B, two antiproliferative and antioxidant triterpenesaponins fromEntada rheedii. Phy tochem. 71(2-3): 254-261.

[20] Nzowa, L.K., Teponno, R.B., Tapondjou, Z.A., Veroota, L., Liao, Z., Graham, D., Zink, M.C. and Barboni, L. (2013) The new tryptophan derivatives from the seed kernel of Entadarheedii effects on cell viability and HIV infectivity. Fitoterapia 87: 37-42.

[21] Ponnaiah Pillai, Yokeswari Nithya. (2018) Assesment of bio-active components present in the whole plant extract of Catharanthus pusillus. International Journal of Creative Research Thoughts, 6 (1), 604-612.

[22] Radha Krishnan K., F. James and A. Mohan. (2016) Isolation and characterization of $n$-hexadecanoic acid from Canthium parviflorum leaves, Journal of Chemical and Pharmaceutical Research, 8(8):614-617.

[23] Rahman, M., Dey, S.K., Hira, A. and Ahmed, A. (2013) Phy tochemical screening and pharmacological activities of Entadascandens seeds. Int. J. Appl. Res. Nat. Prod. 6(1): 2026.

[24] Robertson, D.G. (2005) Metabonomics in toxicology: A review. Toxicol. Sci. 85: 809-22.

[25] Sathyaprabha, G., Kumaravel, S., Ruffina, D. and Praveenkumar, P. (2010) A comparative study on antioxidant, proximate analysis, antimicrobial activity and phytochemical analysis of Aloe vera and Cissusquadrangularis by GC-MS. J. Pharma. Res. 3:2970 2973.

[26] Schmeda-Hirschmann, G. (2014) 4-Methyl-1-hepten-3-one, the Defensive Compound from Agathemera elegans (Philippi) (Phasmatidae) Insecta. Zeitschrift für Naturforschung C, 61(7-8), 592-594.

[27] Shalini Sharma, Amita Kumari, Mamta Sharma. (2016) Comparative GC-MS Analy sis of Bioactive Compounds in Methanolic Extract of Calotropis gigantea (L) W.T. Aiton Leaf and Latex. International Journal of Pharmacognosy and Phy tochemical Research, 8(11); 1823-1827.

[28] Singh, O., Ali, M. and Akhtar, N. (2011) Phenolic acid glucosides from the seeds of Entadaphaseoloides Merill. J. Asan Nat. Prod. Res. 13(8): 1080-1084.

[29] Sufian, M.A., Shafaat,-Al-Mehedi, Md., Rashid, M.A. and Haque, M.R. (2015) Biological investigation of Entadarheedii Spreng. and isolation of Entadamide-A from its seed. Int. J. Phram. 6(7): 411-414.

[30] Sylvestrea, M., Pichettea, A., Longtina, A., Nagaub, F. and
Legaulta, J. (2006) Essential oil analy sis and anticancer activity of leaf essential oil of Croton flavens L. from Guadeloupe. Journal of Ethnopharmacology 103: 99-102.

[31] Teke, G.N., Lunga, P.K., Wab, H.K., Kuicate, J.R., Vilarem, G., Giacinti, G., Kikuchi, H. And Oshima, Y. (2011) Antimicrobial and antioxidant properties of methanol extract fractions and compounds from the stem bark of Entadaabyssinica Stend. ex A. Satabie. BMC Complementary and Alternative Medicine 57: 121-127.

[32] Thamburaj, Suman \& R, Elango \& Chakkaravarthi, K. (2013) Phyto-chemical profiling of Cleistanthus collinus leaf extracts using GC-MS analysis. Research Journal of Pharmacy and Technology, 6, 1173-1177.

[33] Wagner E.G.H., S. Altuvia, P. Romby. 2002. Antisense RNAs in bacteria and their genetic elements, Adv. Genet. 46, 361-398.

[34] Yang, F.Q., Li, S.P., Zhao, J., Lao, S.C., Wang, Y.T., 2007. Optimization of GC-MS conditions based on resolution and stability of analy tes for simultaneous determination of nine sesquiterpenoids in three species of Curcuma rhizomes. Journal of Pharmaceutical and Biomedical Analy sis 43, 7382

[35] Yusuf, A. and Abdullahi, M.I. (2019) The phytochemical and pharmacological actions of Entadaafricana Guill. \&Perr. Heliy on 5(9): e02323.

[36] Zhang, Z. F., \& Zhou, X. Y. (2011) GC/MS analysis on benzene/alcohol extractives of Manglietia Glauca leaves for biomedicine engineering. Advanced Materials Research, $213,475-478$. 